\title{
PENGUKURAN KUALITAS PERBANKAN SYARIAH SEBAGAI UPAYA DALAM PENINGKATAN KESETIAAN NASABAH
}

\begin{abstract}
The banking industri in Indonesia is growing rapidly nowadays. To support their operating system, the banking industriapplies dual-banking system. It is a system where banking serves two kinds of service to the society, that is conventional and sharia.The dual-banking system aim to give them an alternative choice of banking service so that it will increase the growth of financing in the national economic sector. The more customer of thelslamic bank, the more financing activity can be done. As a new comer in the banking industri, Islamic bank should compete with the incumbent of this industri, that is conventional bank. The important aspect to compete with the competitor is service quality. Furthermore, with the high satisfaction and trust of customers on the service of the Islamic bank, the more they will recommend to the society for having a transaction in Islamic bank so that it will help the growth of Islamic banks. This study learns about the customer's assessment of the service quality of Islamic banks in Indonesia. Data were obtained randomly using a questionnaire instrument that adopted from the research of Siddiqi and Amin. The result of this research that analyzed using an ordinary least square model (OLS) shows that the variable of service quality and customer satisfaction significantly effect on customer loyalty of Islamic banks.
\end{abstract}

Keywords : Islamic Bank, Customer Satisfaction, Quality, Trust, Customer Loyality

\section{PENDAHULUAN}

Pertumbuhan industri perbankan syariah di Indonesia saat ini mengalami peningkatan yang cukup pesat. Sebagai pendatang baru di industri perbankan, perbankan syariah telah memberikan alternatif baru bagi nasabah dalam memilih jasa perbankan. Di Indonesia, perbankan syariah tidak semuanya berdiri sendiri, beberapa bank di Indonesia menerapkan dual-banking system atau disebut jugasistem perbankan berganda, dimana sebuah bank menerapkan dua jasa perbankan kepada masyarakat, yaitu konvensional dan syariah. Pelaksanaan dual-banking system di Indonesia sendiri telah dimulai pada tahun 1998 dengan diterapkannya Undang - Undang No. 10 Tahun 1998. Sistem perbankan syariah menjalankan operasinya dengan menerapkan prinsip bagi hasil antara nasabah dan bank. Selain itu perbankan syariah juga mengedepankan prinsip keadilan, etika, nilai kebersamaan dan persaudaraan dalam menjalankan transaksi.

Berdasarkan data yang diperoleh dari Otoritas Jasa Keuangan (OJK), perbankan syariah telah memberikan dampak terhadap pertumbuhan ekonomi di Jawa Tengah yaitu sebesar 5,82\% pada kuartal ketiga 2017. Nilai pertumbuhan ini lebih besar dari nilai pertumbuhan perbankan syariah secara nasional yaitu sebesar 5,3\% (Tribun Jateng, 2017). Berdasarkan Islamic Economic Forum for Indonesian Development (ISEFID) seperti dikutip dari Republika bahwa perbankan syariah perlu untuk memperbaiki kualitas layanan dan memperluas jaringan bisnis, baik dalam peningkatan aset, pembiayaan maupun dana pihak ketiga sehingga perbankan syariah dapat terus bertumbuh. Hasil kajian ISEFID juga menunjukkan bahwa bahwa persebaran 
perbankan syariah masih belum merata yaitu masih terpusat di pulau Jawa.

Pada tahun 2017, OJK mengungkapakan besarnya aset yang dimiliki oleh perbankan syariah adalah sebesar 5,18\% dari total nilaiasetperbankannasional. Perlu kitasadaribahwaasetmerupakanhal yang penting bagi perbankan dalam menjalankan jasa keuangan yang dilakukan. Peningkatan aset dapat berpengaruh terhadap peningkatan pembiayaan dan sebaliknya. Hubungan sebab akibat tersebut dapat didukung dengan adanya peningkatan nasabah. Semakin banyak nasabah di bank syariah maka semakin tinggi pula aktivitas penyaluran dana yang dapat dilakukan. Sebagai pendatang baru dalam industry perbankan, tidak dapat dipungkiri perbankan syariah perlu berkompetisi dengan pendahulunya, yaitu perbankan konvesional yang merupakan perusahaan incumbent dalam industri perbankan. Sebagai pesaing, tentu saja perbankan syariah perlu melakukan terobosan agar dapat bertahan pada industri perbankan.

Dalam industri jasa, khususnya dalam hal ini adalah industry perbankan, Kualitas pelayanan menjadi aspek yang cukup penting yang harus diperhatikan. Siddiqi (2011) menyatakan bahwa kualitas pelayanan merupakan subjek yang sangat menarik dalam industri perbankan. Kepuasan nasabah juga merupakan hal yang penting dalam mempertahankan nasabah. Kepuasan nasabah dapat dijadikan ajang promosi bagi bank. Selain kualitas pelayanan yang diberikan oleh bank, kepercayaan dan image yang diberikan oleh bank merupakan hal yang sangat penting dalam meningkatkan nasabah. Masyarakat tentunya mengharap bahwa karyawan dari bank syariah pastinya paham benar akan produk dan jasa keuangan syariah yang diberikan oleh bank dan bank juga harus bisa meyakinkan bahwa industri yang dijalankan sesuai dengan prinsip syariah. Selanjutnya dengan kepuasan dan kepercayaan yang tinggi dari nasabah, nasabah akan merekomendasikan kepada masyarakat umum untuk melakukan transaksi dengan menggunkan bank syariah sehingga akan dapat membantu bank syariah untuk tumbuh berkembang.

Berdasarkan latar belakang diatas, rumusan masalah yang dapat dirumuskan adalah apakah terdapat pengaruh antara kualitas pelayanan, kepuasan nasabah, serta kepercayaan terhadap kesetiaan nasabah bank syariah. Serta bagaimana persepsi masyarakat pengguna jasa keuangan syariah terhadap pelayanan yang diberikan oleh bank syariah. Penelitian ini secara umum bertujuan untuk memberikan bukti empiris mengenai pengaruh kualitas pelayanan, kepuasan nasabah, serta kepercayaan terhadap kesetiaan nasabah bank syariah. Selain itu, penelitian ini juga bertujuan untuk memberikan penjelasan mengenai persepsi masyarakat pengguna jasa keuangan syariah terhadap pelayanan yang diberikan oleh bank syariah. Keberadaan penelitian ini diharapkan akan mampu memberikan referensi bagi industri perbankan syariah dalam rangka untuk meningkatkan kualitas pelayanan terhadap nasabah. Sedangkan bagi masyarakat umum (termasuk nasabah) penelitian ini diharapkan memberikan gambaran mengenai prospek perbankan syariah di Indonesia, khususnya Semarang.

\section{TINJAUAN PUSTAKA}

\section{Perbankan Syariah}

Bank syariah merupakan bank yang melandaskan kegiatannya pada prinsip syariah, yaitu sebuah aturan mengenai perjanjian yang diatur berdasarkan hukum Islam antara bank dengan pihak lain dalam hal 
penyimpanan dana serta pembiayaan kegiatan usaha atau kegiatan lain yang diatur dengan prinsip syariah. Bank Syariah memiliki perbedaan yang mendasar dengan bank konvensional pada umumnya. Perbedaan ini terletak pada landasan operasi yang digunakan, dimana bankkonvensional beroperasi dengan dasar bunga,sedangkan bank syariah beroperasi berdasarkan pada prinsip bagi hasil, ditambah dengan jual beli serta sewa. Prinsip syariah meyakini bahwa bunga memiliki unsur ribayang tidak diperkenankan oleh agama Islam.

Dalam publikasi laporan perkembangan keuangan syariah yang diterbitkan oleh OJK, perbankan syariah Indonesia memberikan kontribusi yang signifikan terhadap perbankan syariah global yaitu dilihatdari total asetkeuangansyariah global menyumbang sebesar 2,5\%, Sedangkan di tingakt Asia kontribusi perbankan syariah Indonesia sebesar 13,4\%. Meskipun pertumbuhan perbankan syariah telah mampu berkontribusi di tingkat Asia dan Global, di dalam negeri sendiri pertumbuhan perbankan syariah selama 3 tahun terakhir telah menunjukkan perlambatan pertumbuhan. Berikut ini merupakan data perbankan nasional.

OJK juga menyampaikan bahwa aset perbankan syariah masih didominasi oleh Bank Syariah Mandiri dan Bank Muamalat Indonesia. Tidak meningkatnya aset yang dimiliki perbankan syariah juga diungkapkan bahwa industry perbankan masih berfokus pada beberapa prusahaan saya, sehingga apabila terjadi masalah pada perusahaan tersebut akan memberikan dampak yang cukup signifikan terhadap industry perbankan syariah. Berikut adalah market share perbankan syariah.

\section{Kepuasan Nasabah}

Pemenuhan syarat dalam memenuhi kebutuhan pelanggan dapat dilakukan dengan perpaduan perpaduan antara sifat dan karakteristik yang menentukan sejauh mana keluaran atau dengan kata lain dapat disebut dengan kualitas. Konsep kualitas bersifat relatif tergantung persepsi masing-masing. Namun, pada umumnya terdapat tiga orientasi kualitas yang seharusnya konsisten yaitu persepsi, produk/jasa yang diberikan dan proses. Perlu diketahui bahwa untuk jasa, bentuk produk dan proses sulit untuk dibedakan, hal ini disebabkan karena bentuk produk adalah proses itu sendiri. Kontribusi atas konsistensi kualitas suatu jasa terbukti dapat memberikan keberhasilan pada suatu perusahaan (Lupiyoadi, 2013).

John J. Sviokla di dalam Lupiyoadi (2013) menyatakan dalam sebuah proses produksi suatu barang/ jasa, keberadaan kualitas dapat menciptakan suatu persepsi positif dari pelanggan terhadap perusahaan serta menghasilkan suatu kepuasan dan loyalitas pelanggan. Salah satu pendekatan untuk mengukur kualitas jasa yaitu SERVQUAL (service quality). Pada intinya SERVQUAL menunjukkan hubungan antara persepsi pelanggan dengan kenyataan yang dialami oleh pelanggan. Apabila kenyataan melebihi persepsi pelanggan, maka dikatakan kualitas pelayanan memuaskan. Namun, sebaliknya apabila kenyataan yang diterima jauh di bawah apa yang diharapkan pelanggan maka kualitas pelayanan tidak memuaskan. Harapan para pelanggan diperolah dari iklan perusahaan, pencitraan perusahaan di kalangan masyarakat, pengalaman sebelumnya dan berbagai hal lain yang berkaitan dengan perusahaan.

Menurut Singh (2011), kualitas layanan dapat dilihat dari dua perspektif yaitu pelanggan dan bank. Dari perspektif konsumen, kualitas layanan dapat dilihat dari perbedaan antara kualitas yang diharapkan dengan 
kualitas yang diterima. Sedangkan dari perspektif bank yaitu kualitas layanan, dapat dilihat dari pelayanan yang ditargetkan dengan yang diberikan terhadap konsumen.

Penelitian mengenai dimensi kualitas jasa dipelopori oleh Parasuraman, dkk yang menggunakan model SERVQUAL, yang mana memiliki skala pengukuran multiple item scale. Instrumen dalam penelitian tersebut didesain untuk berbagai macam pelayanan dimana menentukan harapan dan persepsi pelanggan akan pelayanan yang diinginkan, serta digunakan untuk mengukur kualitas jasa. Terdapat lima dimensi yang terdapat dalam penelitian Parasuraman, dkk, antara lain:

1. Berwujud (tangible), yaitu eksistensi perusahaan dalam menunjukkan kemampuannya kepada pihak ekternal, atau bukti nyata yang dapat ditunjukkan oleh pemberi jasa.

2. Reliabilitas, merupakan kesesuaian antara harapan nasabah dengan ketepatan pelayanan sesuai dengan yang dijanjikan secara akurat dan terpercaya.

3. Ketanggapan (Responsiveness), yaitu ketepatan dalam memberikan pelayanan yang cepat serta kejelasan informasi yang diberikan.

4. Jaminan dan kepastian (assurance), yaitu bagaimana menumbuhkan rasa kepercayaan para nasabah kepada perusahaan, antara lain: keamanan, kompetensi, kredibilitas dan kesopanan para karyawan.

5. Empati (emphaty), yaitu upaya yang dilakukan perusahaan dalam memberikan perhatian yang tulus sehingga dapat memahami keinginan nasabah, hal ini bersifat individual atau pribadi.

\section{Hasil Penelitian Empirik}

Penelitian mengenai kualitas, kepuasan, dan kesetiaan nasabah perbankan syariah sudah banyak dilakukan oleh peneliti sebelumnya dengan subjek luar negeri. Perbankan syariah di Indonesia sendiri baru dalam masa pertumbuhan. Saqib dan Darooq (2015) meneliti mengenai dampak persepsi kepatuhan akan syariah terhadap kepuasan nasabah di perbankan Pakistan. Hasil menunjukkan bahwa kepatuhan syariah merupakan pemoderasi antara kualitas layanan dengan kepuasan nasabah. Sayani (2014) juga meneliti mengenai faktor penentu yang mempengaruhi kepuasan nasabah di industri perbankan Uni Emirat Arab. Hasil penelitian yang dilakukan Sayani menunjukkan bahwa nasabah bank puas dengan Dewan Penasihat Syariah dan mempunyai hubungan dengan cara bank menangani complain dan jumlah cabang bank juga mempengaruhi kepuasan nasabah.

Penelitian oleh Naser, Jamal dan Khalid (1999) juga meneliti mengenai kepuasan nasabah pada Bank Syariah di Jordan. Mereka menemukan bahwa nasabah mengungkapkan ketidakpuasan mereka terhadap pelayanan dari perbankan syariah, nasabah mengetahui tentang produk yang ditawarkan akan tetapi nasabah tidak menggunakan jasa tersebut. Estiri, Hosseini dan Yazdani (2011) juga melakukan penelitin tentang kepuasan nasabah akan perbankan syariah di Iran. Mereka menemukan bahwa dua faktor dimensi kualitas menjadi faktor penting dalam kepuasan nasabah.

Penelitian tersebut di atas menunjukkan bahwa nasabah sangat berkaitan erat dengan kepuasan terhadap pelayanan yang diberikan oleh perbankan syariah. Hal ini menjadi penting karena telah terbukti bahwa kepuasan nasabah dapat menjadi penggerak peningkatan penggunaan jasa keuangan 
syariah yang dihadirkan oleh perbankan syariah. Dengan demikian, baik secara langsung maupun tidak langsungakanmeningkatkanasetperbankansyariahsehingga dapat berkontribusi lebih dalam perekonomian negara.

\section{Pengembangan Hipothesis}

Kesetiaan nasabah merupakan hal yang sangat penting bagi industri jasa, tidak terkecuali penyelenggara jasa keuangan. Fokus dalam penelitian ini yaitu perbankan syariah dengan alasan karena perbankan syariah sekarang ini dalam proses bertumbuh. Apabila dibandingkan dengan perbankan konvensional tentunyadalamhalasetmasihsangatjauh, dikarenakan perbankan konvensional sudah sejak lama eksis dibidang jasa keuangan. Hasil penelitian dari Siddiqi (2011) mampu membuktikan bahwa kualitas pelayanan, kepuasan nasabah dan kesetiaan nasabah mempunyai hubungan yang signifikan dalam bisnis retail perbankan di Bangladesh. Hasil penelitian dari Amin, dkk (2013) juga membuktikan bahwa kepuasan pelanggan mempunyai hubungan yang signifikan dengan image dan kepercayaan, selanjutnya kepercayaan mempunyai hubungan yang signifikan terhadap kesetiaan.

Semakin tinggi kepercayaan masyarakat terhadap image yang diberikan oleh industry maka masyarakat akan menjadi semakin yakin dan setia untuk menjadi nasabah terhadap industry tersebut khususnya perbankan syariah. Ketika nasabah puas akan pelayanan yang diberikan oleh industry perbankan syariah maka nasabah pun akan semakin setia terhadap perbankan syariah. Berdasarkan uraian diatas hipotesis penelitian ini adalah terdapat pengaruh yang signifikan antara dimensi kualitas, kepuasan, kepercayaan terhadap kesetiaan dalam menggunakan jasa perbankan syariah.

\section{METODE PENELITIAN}

\section{Populasi dan Sample}

Data yang digunakan dalam penelitian ini merupakan data primer berupa jawaban responden yang didapatkan dari kuesioner yang telah didistribusikan dengan menggunakan metode simple purposive random sampling yaitu menyebarkan kuesioner kepada pengguna jasa keuangan dari perbankan syariah di Indonesia, dalamhal ini Jawa Tengah dipilih karena memiliki tingkat pertumbuhan perbankan syariah yang cukup tinggi di Indonesia.Sebagai sampel yakni nasabah yang tersebar di Semarang. Semarang menjadi sampel kami karena seperti yang sudah disampaikan pada latar belakang pertumbuhan perbankan syariah paling tinggi tersebar di Pulau Jawa. Penelitian ini mewakili dari wilayah Jawa Tengah dan penelitian ini berfokus pada ibu kota Jawa Tengah yaitu Semarang.

\section{Variabel Penelitian}

Variabel yang digunakan dalam penelitian ini yaitu kualitas pelayanan yang di dalamnya terdapat pernyataan tentang tangibles, reliability, responsiveness, assurance dan emphaty. Dimensi kualitas yang digunakan dalam penelitian ini yaitu menggunakan dimensi yang diperkenalkan oleh Parasuraman, dkk (1988). Selain menggunakan kualitas pelayanan, penelitian ini juga menggunakan variable oleh Amin yaitu 
kepuasan nasabah dan kepercayaan sehingga dapat menumbuhkan kesetiaan nasabah yang pada akhirnya berdampak padakegiatanmerekomendasikanindustriperbankansyariah. Dalam mengukur dimensi kualitas pelayanan bank syariah dalam penelitian ini dipergunakanlah kuesioner dengan skala likert 5, yang terdiri dari:

1. Sangat Tidak Setuju

2. Tidak Setuju

3. Netral

4. Setuju

5. Sangat Setuju

\section{Teknik Analisis}

Penelitian ini menggunakan alat analisis regresi linear berganda dengan pendekatan ordinary least square serta deskriptif statistik untuk menjabarkan hasil temuan. Model yang dikembangakan dalam penelitian ini adalah sebagai berikut :

$$
Y=\beta_{0}+\beta_{1} X 1+\beta_{2} X_{2}+\beta_{3} X 3+e
$$

Dimana :

$\mathrm{X}_{1}=$ kualitas pelayanan

$\mathrm{X}_{2}=$ kepercayaan nasabah

$\mathrm{X}_{3}=$ kepuasan nasabah

$\mathrm{Y}=$ loyalitas nasabah

\section{Hasil Analisis Data}

\section{ANALISIS DAN PEMBAHASAN}

Pengumpulan data penelitian ini menggunakan kuesioner yang telah didistribusikan kepada nasabah bank syariah di wilayah Semarang. Kuesioner yang didistribusikan mencapai 120 kuesioner dan sebanyak 88 kuesioner layak untuk dijadikan data penelitian. Sebagian kuesioner tidak kembali atau kuesioner yang tidak lengkap dari responden sehingga harus dihilangkan dari sampel penelitian. Sebelum dilakukan uji regresi linier berganda dengan pendekatan ordinary least square, telah dilakukan uji reliabilitas dan validitas dan menunjukkan hasil yang menyatakan bahwa kuesioner reliable dan valid.

Hasil pengujian asumsi klasik dapat ditunjukkan seperti dalam tabel 2. Berdasarkan hasil pengujian Kolmogorov smirnov, dapat dilihat nilai signifikansi sebesar 0,755 yaitu lebih besar dari 0,05 sehingga dapat dikatakan bahwa data terdistribusi secara normal. Selanjutnya dari nilai VIF dan tolerance pada model diketahui bahwa nilai VIF untuk semua variabel $<10$ dan nilai tolerance $>0,1$ sehingga dari hasil tersebut dapat disimpulkan bahwa varibel yang dipergunakandalam model tidak memiliki korelasi satu dengan yang lain, atau dapat dikatakan bahwa model bebas dari masalah multikolinearitas.

Selain itu, dilakukan juga pengujian heteroskedastisitas. Berdasarkan pada grafik sactterplot diketahui bahwa titik - titik menyebar diatas dan dibawah angka nol pada sumbu Y serta tidak membentuk pola tertentu, sehingga dapat dikatakan bahwa model memiliki varians residual yang homogen. Hasil pengujian seperti 
terlihat pada gambar 2 .

Persamaan regresi tersebut menunjukkan bahwa setiap ada peningkatan variable kualitas pelayanan (X1), kepercayaan nasabah (X2), dan kepuasan nasabah (X3) akan meningkatkan pula loyalitas nasabah (Y). Demikian pula apabila tidak terdapat perubahan kenaikan dari kualitas pelayanan (X1), kepercayaan nasabah (X2), dan kepuasan nasabah (X3) akan menyebabkan penurunan loyalitas nasabah (Y).

Berdasarkan hasil pengujian tersebut juga dapat dilihat nilai signifikansi $F$ adalah sebesar 0,000 dimana nilai ini lebih rendah dari taraf signifikansi sebesar 0,05. sehingga dapat dikatakan bahwa secara bersama sama variabel kualitas pelayanan (X1), kepercayaan nasabah(X2), dan kepuasan nasabah (X3) berpengaruh terhadap variabel loyalitas nasabah (Y). Nilai koefisien determinasi juga ditunjukkan sebesar 0,654 yang berarti bahwa sebesar 65,4\% variabel kualitas pelayanan (X1), kepercayaan nasabah (X2), dan kepuasan nasabah (X3) dapat menjelaskan variabel loyalitas nasabah $(Y)$, sedangkan sisanya sebesar $34,6 \%$ dijelaskan oleh variabel selain yang digunakan dalam model.

\section{Variabel Kualitas Pelayanan terhadap Loyalitas Nasabah}

Hasil pengujian secara parsial menunjukkan bahwa nilai signifikansi antara variable kualitas pelayanan terhadap loyalitas nasabah adalah sebesar 0,001. Hal ini menunjukkan bahwa variable kualitas pelayanan berpengaruh terhadap loyalitas nasabah. Variabel kualitas pelayanan meliputi penerapan prinsip Islam, jaminan atas pengetahuan syariah bagi pegawai bank, kehandalan, bukti fisik atau fasilitas dari bank syariah, empati dan daya tanggap.

Indikator pertama dari kualitas pelayanan mengenai penerapan prinsip Islam pada layanan bank Syariah sebanyak 45,5\% responden menyatakan setuju bahwa bank syariah telah menjalankan prinsip Islam dalam kegiatan operasional. Sebagai indicator kedua mengenai jaminan kualitas bank syariah, responden juga telah menyatakan setuju pegawai bank syariah konsisten menjaga kesopanan serta pegawai bank syariah memiliki pengalaman dan pengetahuan yang luas mengenai bank syariah. Dilihat dari sisi kehandalan, bukti fisik, empati dan daya tanggap mayoritas responden menyatakan setuju bahwa bank syariah mampu menunjukkan kualitas pelayanannya terhadap nasabah.

Hal ini membuktikan bahwa kualitas layanan bank syariah baik secara langsung maupun tidak langsung telah mempengaruhi loyalitas nasabah untuk tetap memilih menabung atau bertransaksi dengan menggunakan bank syariah. Hasil penelitian ini mendukung teori yang dinyatakan oleh Siddiqi (2011) yang menyatakan bahwa kualitas pelayanan menjadi aspek yang cukup penting ketika kita harus bersaing dalam industri jasa. Kepuasan nasabah juga merupakan hal yang penting dalam mempertahankan nasabah. Kepuasan nasabah dapat dijadikan ajang promosi bagi bank. Promosi yang cukup efektif yaitu word of mouth (wom), nasabah akan menceritakan apa yang mereka dapatkan, apabila mereka puas dengan pelayanan yang diberikan maka nasabah tersebut akan menceritakan hal yang baik terhadap masyarakat, dalam hal ini calon nasabah, begitu pula sebaliknya apabila mereka mendapat pelayanan yang kurang memuaskan maka nasabah juga akan menceritakan pengalaman tersebut.

Hasil penelitian ini juga sejalan dengan penelitian sebelumnya oleh Sayani (2014) yang menunjukkan 
bahwa Nasabah bank puas dengan Dewan Penasihat Syariah dan mempunyai hubungan dengan cara bank menangani complain dan jumlah cabang bank juga mempengaruhi kepuasan nasabah. Selain itu Naser, Jamal dan Khalid (1999) juga meneliti mengenai kepuasan nasabah pada Bank Syariah di Jordan. Mereka menemukan bahwa nasabah mengungkapkan ketidakpuasan mereka terhadap pelayanan dari perbankan syariah, nasabah mengetahui tentang produk yang ditawarkan akan tetapi nasabah tidak menggunakan jasa tersebut. Estiri, Hosseini dan Yazdani (2011) juga melakukan penelitin tentang kepuasan nasabah akan perbankan syariah di Iran. Mereka menemukan bahwa dua factor dimensi kualitas menjadi factor penting dalam kepuasan nasabah.

Hasil pengujian seperti tertera pada tabel 3 menunjukkan bahwa tingkat signifikansi sebesar 0.156, hal ini berarti variable kepercayaan tidak mempengaruhi loyalitas nasabah bank syariah. Indicator yang digunakan di dalam pengukuran kepercayaan yaitu kepercayaan nasabah dalam memberikan informasi pribadi ke bank syariah, kemudian kepercayaan nasabah terhadap profesionalisme dalam kegiatan operasional perbankan syariah serta kepercayaan nasabah terhadap bank syariah yang selalu memenuhi janji-janjinya. Hasil dari indicator dapat ditunjukkan dalam tabel 5.

Hasil dalam penelitian ini belum mampu membuktikan teori yang diungkapkan oleh Siddiqi (2011) yang menyatakan bahwa selain kualitas pelayanan yang diberikan oleh bank, kepercayaan dan image yang diberikan oleh bank merupakan hal yang sangat penting dalam meningkatkan nasabah. Kepuasan dan kepercayaan yang tinggi dari nasabah dapat meningkatkan loyalitas nasabah serta nasabah akan merekomendasikan kepada masyarakat umum untuk melakukan transaksi dengan menggunkan bank syariah

\section{Variabel Kepuasan Nasabah terhadap Loyalitas Nasabah}

Berikut dalam tabel 6 dan tabel 7 merupakan hasil responden terhadap kepuasan nasabah dan loyalitas nasabah.

Hasil pengujian antara kepuasan nasabah terhadap loyalitas nasabah seperti ditunjukkan pada tabel 3 tingkat signifikansi sebesar 0,000. Hal ini berarti bahwa dalam penelitian ini kepuasan nasabah mempengaruhi loyalitas nasabah. Hasil ini mendukung penelitian yang dilakukan pada Bank syariah di Malaysia oleh Amin, Isa dan Fontaine (2013). Mereka menemukan bahwa adanya hubungan yang signifikan antara kepuasan nasabah dengan loyalitas nasabah. Naser, Jamal dan Khalid (1999) juga menyatakan bahwa kepuasan akan jasa dan produk yang diberikan oleh bank syariah mempengaruhi loyalitas. Selain itu, hasil dari Sayani (2015) juga menemukan bahwa nasabah bank syariah puas akan layanan yang diberikan oleh bank syariah, hal yang penting juga mengenai reputasi dan menangani masalah.

\section{KESIMPULAN}

Hasil penelitian yang dilakukan menunjukkan bahwa variable kualitas pelayanan dan kepuasan nasabah mempengaruhi loyalitas nasabah. Kualitas pelayanan menjadi aspek yang cukup penting ketika kita harus bersaing dalam industri jasa. Kepuasan nasabah juga merupakan hal yang penting dalam mempertahankan nasabah. Kepuasan nasabah dapat dijadikan ajang promosi bagi bank. Promosi yang cukup efektif yaitu word of mouth (wom), nasabah akan menceritakan apa yang mereka dapatkan, apabila mereka puas dengan pelayanan 
yang diberikan maka nasabah tersebut akan menceritakan hal yang baik terhadap masyarakat, dalam hal ini calon nasabah, begitu pula sebaliknya apabila mereka mendapat pelayanan yang kurang memuaskan maka nasabah juga akan menceritakan pengalaman tersebut. Selanjutnya, semakin tinggi kepuasan nasabah akan produk dan jasa yang diberikan, maka akan semakin tinggi pula loyalitas nasabah terhadap bank syariah. 


\section{DAFTAR PUSTAKA}

Ali, S. N. 2017. Building trust in Islamic finance products and services. Society and Business Review, vol 12 issue: 3, pp: 356-372.

Amin, M., Isa, Z., and Fontaine, R. 2013. Islamic banks: Contrasting the drivers of customer satisfaction on image, trust, and loyalty of Muslim and non-Muslim customers in Malaysia. International Journal of Bank Marketing, vol. 31 issue: 2, pp. 79-97.

DetikFinance. 2017. Perbankan Syariah RI Lambat Berkembang, Ini Penyebabnya, dikutip dari https://finance. detik.com/moneter/3578220/perbankan-syariah-ri-lambat-berkembang-ini-penyebabnya pada 13 Desember 2017.

Estiri, M., Hosseini, F., Yazdani, H., and Nejad, H. J. 2011. Determinantsof customer satisfaction in Islamic banking: evidence from Iran. International Journal oflslamic and Middle Eastern Finance and Management, Vol. 4 Issue: 4, pp.295-307.

Naser, K., Jamal, A., and Khalid Al-Khatib. 1999. Islamic banking: a study of customer satisfaction and preferences in Jordan. International Journal of Bank Marketing, vol. 17 issue: 3, pp: 131-151.

Republika. 2017. Bisnis Bank Syariah 2017 Berpeluang terus Melonjak, Ini Alasannya, dikutip dari http:// www.republika.co.id/berita/ekonomi/syariah-ekonomi/17/01/18/ojy976382-bisnis-bank-syariah-2017berpeluang-terus-melonjak-ini-alasannya pada 13 Desember 2017.

Saqib, L. and Farooq, M. A. 2015. Customer perception regarding Shari'ah Compliance of Islamic Banking Sector of Pakistan. Journal of Islamic Accounting and Business Research, vol. 7 issue: 4, pp. 282-303.

Sayani, H. 2015. Customer satisfaction and loyalty in the Unite4d Arab Emirates banking industry. International Journal of Bank Marketing, vol. 33 issue: 3, pp: 351-375.

Siddiqi, K., O. 2011. Interrelations between service quality attribute4s, customer satisfaction and customer loyalty in the retail banking sector in Bangladesh. International Journal of Business and Management, vol 6, no.3.

Sumaedi, S., Juniarti, R. P., and I Gede Mahatma Yuda Bakti. 2015. Understanding trust \&commitment of individual saving customers in Islamic banking: The role of ego involvement. Journalof Islamic Marketing, Vol. 6 Issue: 3, pp.406-428.

Tribun Jateng. 2017. Industri Perbankan Syariah di Jawa Tengah Tumbuh 5,82 persen, dikutip dari http://jateng. tribunnews.com/2017/10/25/industri-perbankan-syariah-di-jawa-tengah-tumbuh-582-persen pada 13 Desember 2017. 


\section{LAMPIRAN}

Tabel 1. Indikator Utama Perbankan Nasional

\begin{tabular}{lccccc}
\hline Indikator & $\mathbf{2 0 1 2}$ & $\mathbf{2 0 1 3}$ & $\mathbf{2 0 1 4}$ & $\mathbf{2 0 1 5}$ & $\mathbf{2 0 1 6}$ \\
\hline Total Aset (Rp Trilliun) & 4,330 & 5,032 & 5,705 & 6,198 & 6,843 \\
\hline Pertumbuhan Aset (yoy) & $16,7 \%$ & $16,2 \%$ & $13,4 \%$ & $8,64 \%$ & $10,41 \%$ \\
\hline Total Kredit (Rp Trilliun) & 2,708 & 3,293 & 3,674 & 4,058 & 4,377 \\
\hline Total DPK (Rp Trilliun) & 3,225 & 3,664 & 4,114 & 4,413 & 4,836 \\
\hline CAR & $17,43 \%$ & $18,13 \%$ & $19,57 \%$ & $21,39 \%$ & $22,93 \%$ \\
\hline ROA & $3,11 \%$ & $3,08 \%$ & $2,85 \%$ & $2,32 \%$ & $2,23 \%$ \\
\hline LDR & $83,58 \%$ & $89,70 \%$ & $89,42 \%$ & $92,11 \%$ & $90,70 \%$ \\
\hline BOPO & $74,10 \%$ & $74,08 \%$ & $76,29 \%$ & $81,49 \%$ & $82,22 \%$ \\
\hline NPL & $1,87 \%$ & $1,77 \%$ & $2,16 \%$ & $2,49 \%$ & $2,93 \%$ \\
\hline NIM & $5,49 \%$ & $4,89 \%$ & $4,23 \%$ & $5,39 \%$ & $5,63 \%$ \\
\hline
\end{tabular}

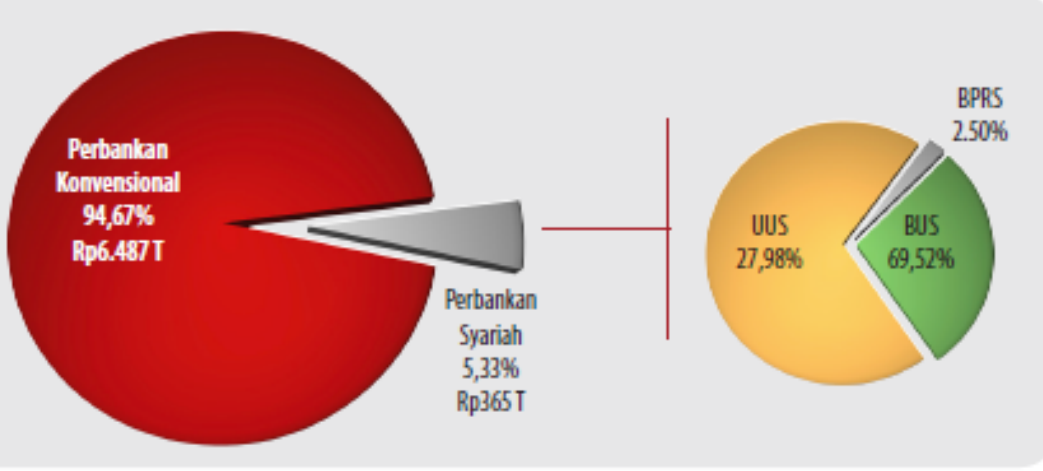

Total Aset Perbankan Nasional posisi Desember 2016 Rp6.852 triliun

Gambar 1. Total Aset Perbankan Syariah 
Tabel 2. Pengujian Asumsi Klasik

\begin{tabular}{lccc}
\hline & \multicolumn{3}{c}{ Variabel } \\
\hline X1 & $\mathbf{X 2}$ & $\mathbf{X 3}$ \\
\hline VIF & 3,368 & 1,428 & 2,836 \\
\hline Tolerance & 0,297 & 0,7 & 0,353 \\
\hline $\begin{array}{l}\text { Kolmogorov-Smirnov } \\
\text { (Sig) }\end{array}$ & & 0.75486692 & \\
\hline
\end{tabular}

Scatterplot

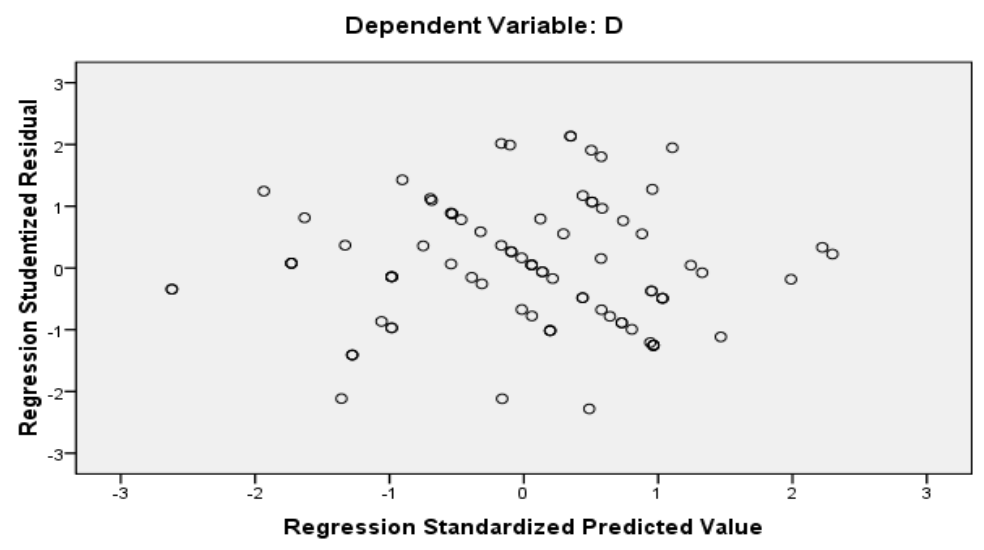

Gambar 2. Pengujian Heteroskedastisitas

Tabel 3.Hasil Pengujian Hipotesis

\begin{tabular}{ccc}
\hline & $\mathrm{t}$ & $\mathrm{Sig}$ \\
\hline $\mathrm{X} 1$ terhadap $Y$ & 3.52 & 0.001 \\
\hline $\mathrm{X} 2$ terhadap $Y$ & 1.431 & 0.156 \\
\hline $\mathrm{X} 3$ terhadap $Y$ & 3.659 & 0,000 \\
\hline F =55,736 & & 0,000 \\
\hline Adjusted R Squared & 0,654 & \\
\hline
\end{tabular}


Tabel 4. Hasil Responden terhadap Kualitas Pelayanan

\begin{tabular}{|c|c|c|c|c|c|}
\hline Variabel & SS & Setuju & Netral & TS & STS \\
\hline $\mathrm{X} 1.1$ & $38,6 \%$ & $45,5 \%$ & $12,5 \%$ & $3,4 \%$ & 0 \\
\hline $\mathrm{X} 1.2$ & $40,9 \%$ & $59,1 \%$ & 0 & 0 & 0 \\
\hline $\mathrm{X} 1.3$ & $29,5 \%$ & $56,8 \%$ & $13,6 \%$ & 0 & 0 \\
\hline$X 1.4$ & $11,4 \%$ & $76,1 \%$ & $12,5 \%$ & 0 & 0 \\
\hline X1.5 & \multicolumn{2}{|c|}{$\begin{array}{l}12,5 \% \\
58 \%\end{array}$} & $25 \%$ & $4,5 \%$ & 0 \\
\hline$X 1.6$ & $20,5 \%$ & $63,6 \%$ & $13,6 \%$ & $2,3 \%$ & 0 \\
\hline $\mathrm{X} 1.7$ & $18,2 \%$ & $61,4 \%$ & $20,5 \%$ & 0 & 0 \\
\hline $\mathrm{X} 1.8$ & $23,9 \%$ & $60,2 \%$ & $15,9 \%$ & 0 & 0 \\
\hline X1.9 & $29,5 \%$ & $67 \%$ & $3,4 \%$ & 0 & 0 \\
\hline$\times 1.10$ & $8 \%$ & $72,7 \%$ & $17 \%$ & $2,3 \%$ & 0 \\
\hline $\mathrm{X} 1.11$ & $20,5 \%$ & $48,9 \%$ & $28,4 \%$ & $2,3 \%$ & 0 \\
\hline$\times 1.12$ & $23,9 \%$ & $50 \%$ & $21,6 \%$ & $4,5 \%$ & 0 \\
\hline $\mathrm{X} 1.13$ & $33 \%$ & $54,5 \%$ & $10,2 \%$ & $2,3 \%$ & 0 \\
\hline $\mathrm{X} 1.14$ & $19,3 \%$ & $62,5 \%$ & $12,5 \%$ & $5,7 \%$ & 0 \\
\hline X1.15 & $14,8 \%$ & $54,5 \%$ & $28,4 \%$ & $2,3 \%$ & 0 \\
\hline $\mathrm{X} 1.16$ & $13,6 \%$ & $70,5 \%$ & $15,9 \%$ & 0 & 0 \\
\hline X1.17 & $22,7 \%$ & $52,3 \%$ & $25 \%$ & 0 & 0 \\
\hline
\end{tabular}

Tabel 5. Hasil Responden terhadap Kualitas Pelayanan

\begin{tabular}{|c|c|c|c|c|c|}
\hline Variabel & SS & Setuju & Netral & TS & STS \\
\hline$X 2.1$ & $13,6 \%$ & $33 \%$ & $40,9 \%$ & $6,8 \%$ & $5,7 \%$ \\
\hline$X 2.2$ & $11,4 \%$ & $77,3 \%$ & $11,4 \%$ & 0 & 0 \\
\hline$X 2.3$ & $12,5 \%$ & $59,1 \%$ & $27,3 \%$ & $1,1 \%$ & 0 \\
\hline
\end{tabular}


Tabel 6. Hasil Responden terhadap Kepuasan Nasabah

\begin{tabular}{cccccc}
\hline Variabel & SS & Setuju & Netral & TS & STS \\
\hline$\times 3.1$ & $15,9 \%$ & $61,4 \%$ & $17 \%$ & $5,7 \%$ & 0 \\
\hline$\times 3.2$ & $20,5 \%$ & $54,5 \%$ & $18,2 \%$ & $6,8 \%$ & 0 \\
\hline$\times 3.3$ & $20,5 \%$ & $59,1 \%$ & $14,8 \%$ & $5,7 \%$ & 0 \\
\hline$\times 3.4$ & $20,5 \%$ & $64,8 \%$ & $14,8 \%$ & 0 & 0 \\
\hline$\times 3.5$ & $19,3 \%$ & $48,9 \%$ & $27,3 \%$ & $4,5 \%$ & 0 \\
\hline$\times 3.6$ & $27,3 \%$ & $61,4 \%$ & $11,4 \%$ & 0 & 0 \\
\hline
\end{tabular}

Tabel 7. Hasil Responden terhadap Loyalitas Nasabah

\begin{tabular}{cccccc}
\hline Variabel & SS & Setuju & Netral & TS & STS \\
\hline $\mathrm{Y} 1.1$ & $18,2 \%$ & $67 \%$ & $11,4 \%$ & $3,4 \%$ & 0 \\
\hline $\mathrm{Y} 1.2$ & $10,2 \%$ & $71,6 \%$ & $18,2 \%$ & 0 & 0 \\
\hline $\mathrm{Y} 1.3$ & $12,5 \%$ & $68,2 \%$ & $18,2 \%$ & $1,1 \%$ & 0 \\
\hline $\mathrm{Y} 1.4$ & $26,1 \%$ & $52,3 \%$ & $17 \%$ & $4,5 \%$ & 0 \\
\hline
\end{tabular}

